\title{
Pagan Gods and Allegory in the Ylias by Joseph of Exeter
}

\author{
Roman R. Shmarakov \\ National Research University Higher School of Economics (HSE) in St. Petersburg, \\ 123, nab. kanala Griboedova, St. Petersburg, 190068, Russian Federation; rshmarakov@hse.ru
}

For citation: Roman R. Shmarakov. Pagan Gods and Allegory in the Ylias by Joseph of Exeter. Philologia Classica 2019, 14 (2), 239-248. https://doi.org/10.21638/11701/spbu20.2019.205

\begin{abstract}
This article traces the reception of pagan concepts (mythological figures, formulae of heroic poems) in Latin poetry of the $12^{\text {th }} \mathrm{c}$. In his Ylias (2. 1-14), Joseph of Exeter creates a passage that can be both read in heathen (when uttered by a character) and Christian (as coming from the author) paradigm. Furia Allecto tormenting Priam is allegorised to stand for "sinister thought" (mala cogitatio). This interpretation is widely used; it is found, for example, in the Architrenius by John of Hauville. Pallas protecting the Troyan citadel from the furies is both a figure of myth and stands for wisdom confronting the passions. The expression "the dead of your exile" (funera exilii tui) can be read through a Christian lens (meaning people who died before Christ), as well as through a Platonic one: earth is a place of exile for souls while their homeland is in the skies. This passage, which allows for a double interpretation, prepares the reader for the dream of Paris at the end of book two (the dream motive itself existed already in the antiquity stemming from the rationalistic rethinking of the Judgment of Paris). Joseph of Exeter described the Judgment of Paris in such a way that it can be interpreted both from the pagan and Christian standpoint. It breeds tragic irony: Paris triumphs, having acquired the benevolence of the goddess, but a Christian reader anticipates the death of the hero who deified his own voluptuousness.
\end{abstract}

Keywords: Medieval Latin epics, allegory, interpretatio Christiana.

When Boileau in The Art of Poetry condemns the "criminal mixture" (le mélange coupable) admissible for modern authors of heroic poems, he implies the intolerable combination of a Christian subject with ancient mythological elements. The problem of limits and methods in the reception of mythological content was equally topical for the classicizing poetry of the High Middle Ages. It was even more complicated when a Christian poet turned to the mythological apparatus of Virgil and Statius and developed an ancient subject. Such an author faced the need to find a way to distance himself from his own

(C) St. Petersburg State University, 2019 
material and to make it clear to the public. ${ }^{1}$ One particular example our article examines is the mechanisms of what Erwin Panofsky, when speaking about the 12th century Renaissance, called "interpretatio Christiana” (Panofsky 1972, 83-86).

In the early 1180s Joseph, an Englishman from Exeter who studied in Reims, writes a Latin hexametric poem known today as De bello Troiano or the Ilias ${ }^{2}$ which is based on Historia de excidio Troiae by Dares Phrygius. Scholarship on this work in general and on the below treated subject in particular is rather scarce, thus the discussion between Hugh Parker and Arthur Rigg, two reputable medievalists, is worth a reference. In an article concerned with pagan gods in Joseph's work, Parker (1995) confronts Rigg stating in A history of Anglo-Latin literature, 1066-1422 that "he introduces pagan spirits and deities (Allecto in Book II, Juno and Athena in Book V) to motivate the action, much as Chaucer does with planetary gods" (Rigg 1992, 102). According to Parker, gods in the Ylias only personify different phenomena they are rigidly connected with and do not act where these phenomena lack. When in fear for Achilles Thetis turns the floating bodies over to examine them (Ylias. 5. 381-384), Joseph simply personifies the waves, carrying the bodies of the slaughtered, in order to add a pathetic element to the description of a mass death. However, his Thetis has no influence on the course of events which she enjoys in the works of Homer or Statius. As opposed to the stated, Thetis does not come to her son either in the time of his treacherous murder, or even after it (6. 406-470). Since this scene takes place far from the sea, the personification of this element has no access to it. The same is true for Aurora mourning her son Memnon not immediately after his death, but on the following day (crastina... Aurora: Ylias 6. 370); i. e. she appears only when it is permissible for day to break. Acting like this Thetis and Aurora are hardly anything more than personifications of nature, but Joseph composes so skillfully that they seem to be taking part in the plot. At the same time, Minerva, keeping Achilles by the very gates of Troy (6. 369), is merely a personification of prudence. The meeting of Achilles and Minerva at the battlefield might have resulted in a convincing speech of the goddess, or even in a speech contest, but Joseph avoids it. The author gives goddesses an opportunity to speak extensively only in the dream of Paris, impugning thus any reality of what is happening. To conclude, Parker cites Summa de coloribus rhetoricis by Geoffrey of Vinsauf, ${ }^{3}$ showing that metonymies of this type make up an integral part of the technique of Joseph's times.

Rigg answered Parker's essay six years later (Rigg 2001) agreeing with his idea that gods in Joseph's poem personify natural phenomena. However, he also added that this does not exhaust Joseph's perspective on pagan religion. Rigg singles out five types of Joseph's treatment of paganism, citing one case that falls within the immediate scope of the present study.

At the end of book one, Priam rebuilds Troy after the war with Hercules; book two starts with the apparition of the Fury. The poet says that Priam could have been happy had the gods and fates allowed him. But Allecto sees that the stronghold she shattered is

1 An example of a study on this topic: Kratz 1980; basing on Waltharius and Alexandreis a medieval author is shown to be able to express his critical attitude to the basic ethic rules of a heroic poem, remaining within the framework of its genre limitations.

${ }^{2}$ Henceforth, we refer to it as the Ylias, the title it bears in the critical edition by L. Gompf (1970); the same edition is used for quotations.

3 Significatio autem est quando per unum significatur aliud, ut per 'Jovem' 'aer superior,' per 'Junonem' 'aer inferior,' per 'Phoebum' 'sol,' per 'Eolum' 'ventus,' per 'Plutonem' 'Tartarus,' per 'Neptunum' 'mare,' per 'Cererem' 'seges,' per 'Tetidem' 'aqua,' per 'Bachum' 'vinum' (Parker 1995, 277). 
enjoying a better lot. So in wrath she says: "Will an earthy kingdom always provoke me, the powerful queen of hell and earth, and one day, I hope, of heaven too? What shame is mine! Troy is still standing, provocatively prosperous after the defeat by the Greeks who were my agents. Does Troy put my triumph in question and refuse to admit defeat? May it collapse quickly, this city that was placed in my power at its very foundation!"4 On uttering this, Allecto haunts Priam, reminding him of his sister Hesione held captive by the Greeks (2.1-14). The tirade follows:

O hominum superumque pater! Si numina curas,

Cur hominem plectis? Miserene quod incola terre, Despicitur? Certe lacrimis noctique dedisti

Proscriptas a luce animas. Pater optime, tandem

Flectere, redde polo reduces vel funera saltem

20

Exilii tutare tui! Cur impia sevit

Allecto in miseros? Cur Pergama dia fatigat

Tot superis confisa suis? Tolle, inclita, tolle,

Virgo, moras nec passa premi, quas incolis, arces

Gorgone pretenta Stigias perstringe Medusas!

En aras, en thura sibi communia poscunt

Nutrices scelerum Furie noctisque tirannos

Exorare iubent. Celum intra menia clausum,

Concives habuisse deos haut linquet inultum

Thesiphone regique suo cultore negato,

30

Quam dedit, invidiam Frigius luet.

"O father of the gods and men! If you care about deities, why do you chastise the human? Or is he despicable, for he dwells on the miserable Earth? For certain you immerged in tears and darkness the souls removed from the light. Best of fathers, yield at last, return to the heavens the ones who are returning (redde polo reduces), or at least protect the dead of your exile! Why is impious Allecto raging against the miserable? Why does she oppress the great Pergamum, which relies on so many of its gods? Do not linger, most glorious maiden, do not let shatter the stronghold you abide in; protruding a Gorgon in front of you, restrain the Stygian Medusas! Here, the Furies, the fosterers of crime, demand that they share your sanctuaries and incense and order to pray to the lords of the night. Tisiphone will hardly leave it unavenged that the heavens are locked in these walls, that gods are fellow citizens here; the Phrygian will atone for the hatred he created by refusing veneration to her king (Pluto)." (Translation mine.)

Rigg concludes that this passage, "which requires us either to praise Joseph for an imaginative construction of a half-pagan half-Christian poet, or to condemn him as a bungler", is either a plain case of incapability or a brave attempt to create a pagan world anew in a Christian context. This tirade cannot be attributed to Priam (due to the verses 17-20 and also because he cannot be aware that he is being disturbed by a Fury ${ }^{5}$ ). This means that it belongs to the poet himself. Meanwhile the tirade is addressed to Jupiter and Pallas and contains many references to the Furies. At the same time verses 17-18 ("souls

4 Translation by A. K. Bate $(1986,73)$.

5 A doubtful argument. Right after this, Priam writes an epistle to Greek leaders in which he also complains about "a wicked Erinye mocking at the world" (que dira orbem deludit Herinis: 2. 48). Joseph constructs a pagan character, knowing that at any minute, without even being aware of it, he may fall prey to the Furies. 
removed from the light") hint at the Fall and the expulsion from Paradise. In this case Jupiter is identified with the God of the Genesis. And Joseph asks this higher god to give the heavens back to people or at least to protect funera exilii tui (vv. 19-20). This apparently means "the dead of your exile", i. e. those who died in the exile laid on by the God. In other words, Joseph identifies Jupiter with the God of the Old Testament, puts Trojans and Greeks among other pre-Christians, and creates an image of a poet (a poet-persona) who lived in the times of the Trojan war before the redemption of Christ and hardly knew anything about the whole scheme of Christian history. This hypothesis entails new difficulties, i.e. the absence of any strict demarcation between what Joseph says himself and what is said by the assumed "Dares-poeta". The confusing passage can be seen as some kind of incongruity resulting from distraction, a Christian highlight in a pagan context, but also as an unfinished attempt to create a new outlook (Rigg 2001, 27).

We intend to show that all the problematic passages, underlined by Rigg, can be interpreted both from pagan and Christian or neutral points of view, i.e. are compatible with both pagan and Christian thinking.

\section{Hominum superumque pater}

This formulaic syntagm may refer both to Jupiter and the Christian God. It belongs to the clichés modelled on Virgil ${ }^{6}$ and widely spread in late ancient and medieval poetry. Cf. rerum pater unicus (Juvencus Evangeliorum libri 1. 16; cf. Verg. G. 4. 382); pater superum (Sid. Apoll. Carm. 7. 17), terrarum caelique sator (Boet. Cons. 3. m9. 2), praepollens hominum rerumque creator (Alcimus Avitus De sententia Dei 384), omnipotens genitor, virtus et gloria rerum, / certa salus mundique sator (Corippus Iohannis 7. 88-89), omnipotens hominum sator atque creator (Walafridus Strabus Visio Wettini 733) etc. In the Christian context superi should be understood as angeli. ${ }^{7}$ The speech of Venus at the counsel of the gods evidently became a model for this passage (Verg. Aen. 10. 18-62). The address to Jupiter that opens the speech (o pater, o hominum rerumque aeterna potestas), the image of the raving Allecto (superis immissa repente / Allecto medias Italum bacchata per urbes), the return of motherland to exiles (Xanthum et Simoenta / redde, oro, miseris; cf. redde polo reduces) are the main points reinterpreted by Joseph.

\section{Address to Athena and mentioning of the Furies}

Allecto's attack on Priam is usually compared to the scene from the Aeneid (7. 292405), where angry Juno entrusts Allecto with taking her revenge on the Trojans. The resemblance is obvious: Allecto troubles the king (in Virgil - the queen), whose sister (in Virgil - daughter) is soon to become the wife of a stranger. While in Virgil Allecto is instrumental to Juno, Joseph grants the initiative to Allecto herself and motivates it throughout the monologue. Not underestimating the importance of Aeneid for this passage, the prototype for this part of the Ylias could be found in the initial scene of Claudian's invec-

6 Divum pater atque hominum rex (Aen. 1. 65; 2. 648; 10. 2; 10. 743); pater... superum (Aen. 6. 780); hominum sator atque deorum (Aen. 1. 254; 11. 725; cf. summe deorum / terrarumque sator: Stat. Theb. 1. 178-179), o pater, o hominum rerumque aeterna potestas (Aen. 10. 18); hominum rerumque repertor (Aen. 12. 829) etc.

7 Cf. quite Christian verses addressed by Eriugena to King Charles the Bald: Lux superans animas hominum superumque deorum / agmina (Iohannes Scottus Carm. 7. 1-2). 
tive In Rufinum. ${ }^{8}$ Commentators have, as yet, passed it unnoticed. In particular, A. K. Bate believes that Joseph invented Allecto's intention to be the queen of heavens (Bate 1986, 167), while it was cast over by Claudian who makes Allecto lament over Jupiter chasing the Furies from Olympus and also wants Stygiis invadere nubibus astra (Claud. Ruf. 1. 50. 62). The medieval Allecto echoes Claudian's one: both are insulted by the peace that has settled in the world and eager to destroy it.

However, Joseph is not bound by this model. In about 20 verses Claudian sets the scene: Allecto calls on all the infernal servants for a meeting, and Discord, Famine, Senility, Need, and other suchlike images come to sit on the iron chairs in the "sullen curia", while Allecto, throwing her snakes behind, starts her speech in front of them (Claud. Ruf. 1. 27-44). Joseph draws neither the environment, nor the addressees, thus it remains unclear where and to whom Allecto pours her complaints and threats.

Apparently, these transformations of classical examples are the result of a non-classical interpretation of the Furies. Apart from a widely spread treatment of Allecto as impausabilis 'unstoppable', maintained by the authority of Fulgentius, ${ }^{9}$ there is more to her: sine requie 'without peace. ${ }^{10}$ Joseph's Allecto "depriving Priam of peace" (quietem invidet Priamo: 2. 12-13) can be regarded as a transparent etymological hint. ${ }^{11}$

Besides, Allecto, Tisiphone, and Megaera often stand for evil thoughts, evil speech and evil actions (mala cogitatio, mala locutio et mala operatio). Bernardus Silvestris, the elder contemporary of Joseph of Exeter, writes: "Eumenides tres sunt filie Noctis et Acherontis, scilicet Allecto, Thesiphone, Megera. Per Acherontem ut dictum est accipimus dolorem qui in Nocte, id est in ignorantia animi, procreat et gignit tres sorores. Prima est Allecto que interpretatur prava cogitatio; secunda Thesiphone, id est vox supposita male cogitationi, sermo scilicet malus; tercia Megera, mala operatio" (Jones, Jones 1977, 69). ${ }^{12}$ Johannes de Hauvilla in his poem Architrenius written in about 1184, stages this interpretation entrusting the Furies with strictly divided duties:

\begin{abstract}
Dira sibi triplex hominem partitur et omnes
Distrahit humanos affectus, facta, loquelas:

Inquinat Allecto serve presepia mentis

Affectusque pios, sacrumque forinsecat ignem;

Iuris precipitat equum in declive Megera

Errantesque manus enormibus implicat actis;

Thesiphone linguas agitat scelerumque palude

Inficit eloquii currus auriga loquendi
\end{abstract}

(Architrenius 7.253-260).

${ }^{8}$ In the years when Joseph was writing the Ylias, Claudian's invective was bread and butter for yet another renowned Latin poet: Alain of Lille draws on it liberally in his Anticlaudianus.

9 Fulg. Myth. 1. 7: Allecto enim Grece inpausabilis dicitur. Cf. Lact. Plac. In Theb. 1. 477; I Vat. myth. 2. 8; II Vat. myth. 12; III Vat. myth. 6. 23.

${ }^{10}$ Cf. Glossae in Alexandreidem 2. 342: Alleto quasi sine leto et sine requie (Colker 1978, 320). Two receptions can be easily joined. Glossae in Graecismum 10. 221-222: Allecto interpretatur inpausabilis et sine requie, et dicitur ab a quod est sine et lectos requies, quasi sine requie (Wrobel 1887, 85). See also Clarke, Giles 1973, 30.

${ }^{11}$ Cf. Isid. Etym. 8. 11. 95: Quae ideo Furiae appellantur, quod stimulis suis mentem feriant et quietam esse non sinant.

12 Cf. Glossae in Alexandreidem (Colker 1978, 341, 476); Guillelmus de Conchis Glosae super Boetium 3. m12. 32 (Nauta 1999, 208). 
"The three Furies divide a man among themselves, and reduce all human beings to feelings, deeds and words. Allecto defiles the precincts of the obedient mind, and dispels the sacred fire. Megaera causes the sense of right to decline, and involves our hands in terrible acts. Tisiphone, taking over the reins of speech, drives the tongue and the chariot of eloquence through the swamp of wickedness." ${ }^{3}$

Allecto's actions described by Joseph conform with this pattern: she is an "evil thought" and nothing more. It could be said that the Furies in Joseph's poem are viciousness personified, divided into three spheres of human activity. But the Furies are embedded in some kind of a plot: they seek worship in Troy; they are to be curbed by Pallas, protecting the city, etc. And since it is impossible for one image only to have an allegoric significance while others do not, could this entire passage be interpreted allegorically?

Minerva is traditionally interpreted as a personification of wisdom or contemplative life (Fulg. Myth . 2. 68); arx 'citadel' is twice named in this passage of the Ylias ${ }^{14}$ and is a Platonic metaphor for the head as an acropolis where reason dwells. ${ }^{15}$ Thus, the fight between the Furies and Minerva for the Trojan stronghold could mean for the author of the Ylias the fight of wisdom against passions for the human spirit. To support these abstract considerations, we shall analyse which place the scene with Allecto takes in the composition of book two of the Ylias.

Book two ends with the scene of the Judgment of Paris in the form in which it was inherited by Joseph from the rationalising variant of Dares Phrygius. Paris sees a dream where he is visited by three goddesses asking for his judgment, and each of them making a long speech, praising herself and defaming the rivals. There are several important bridges spanning this dream and the episode with Allecto.

The lexical bridge is the first of these. The apostrophe to Pallas: "protruding a Gorgon in front of you, restrain the Stygian Medusas" (Gorgone pretenta Stigias perstringe Medusas: 2.24 ) is referred to in the speeches of all the three goddesses. The very first mentioning of Pallas in the speech of Juno is accompanied by two mythological epithets: Pallada Gorgoneam bellatricemque Medusam (2.251). Pallas herself repeats this formula (sensit valuisse Medusam / Gorgoneamque deam: 2. 383-384). And finally, Venus names Gorgon (victrix Persee Gorgonis umbra: 2. 518). Neither Medusa, nor Gorgon are mentioned ever again in the entire poem. Such choice of vocabulary marks the importance of the topic Pallas against the Furies, but also hints that the interpretation problems arising in book two of the poem are solved within the poem itself.

Secondly, Claudian models feature prominently. The invective In Rufinum as a model for the speech of Allecto is mentioned above. And this is not the only time when Claudian influences Joseph's poem. When in the dream of Paris it is Pallas's turn to speak, she tells

13 Translation by W. Wetherbee (1994).

14 V.4, of Allecto: quas fregerat, arces; v. 23, of Pallas: quas incolis, arces; mark, how close these phrases are.

15 Pl. Ti. 70a; Cic. Nat. Deor. 2. 140; Apul. De dogm. Plat. 1. 13; Claud. IV Cons. Hon. 235-236; Macrob. In Somn. 1. 6. 81, et al. Bernardus Silvestris writes: Civitas ergo Enee est corpus humanum quod spiritus humanus incolit et regit ideoque eius civitas dicitur. Iterum quemadmodum in civitate sunt quattuor mansionum divisiones et quattuor hominum ordines illas mansiones incolentes, ita quoque in humano corpore quattuor sunt mansiones et potentie sedem in illis habentes. Prima civitatis mansio est arcs, quam sapientes incolunt; ita in corpore prima et eminentior mansio et arcs corporis est capud, in quo sapientia sedem habet. (Jones, Jones 1977, 15). 
how since the beginning of time she has patronised virtues and chased the Furies away (2. 352-370):

Cum vetus efflueret in regnum mobile mundus
Terrarumque notas ultrix detergeret unda,
Emersit cum sole Fides; mox cetera dudum
Nacta fugam virtus terris offensa profanis
Iam mundo meliore redit: Prudentia numquam
Velox, indulgens Pietas, Patientia victrix,
Strenua Simplicitas, hylaris Pudor, Ardor Agendi
Sobrius et nullo nutans Constantia casu;
Non vaga Pax aderat, rerum Concordia custos,
Iusticie rectique tenor. Sine vindice stabant
Visure populos et Deucaliona sorores
Poscebantque ducem; nec enim secura meandi
Copia nec prorsus Furiis in Tartara pulsis
Cessavere metus. Tandem genitura Minervam
Contremuit frons celsa Iovis totusque rotatu
Intonuit maiore polus, nec letior umquam
Lux superis. Hoc patre fluens, hoc edita partu
Divum pandit iter, Diras et monstra relegat
Virtutum custos, virtutum previa Pallas.

"When the old world was washed away into the sea and the avenging flood cleansed the stains of the earth, Trustworthiness came out with the sun. Immediately the other virtues that had long since fled, offended by the sinful lands, returned now that the world was better: Prudence, never in a hurry, kind-hearted Piety, triumphant Patience, eager Simplicity, cheerful Chastity, sober Charity, and Constancy that does not waver in any misfortune; Peace the traveler's friend, Concord the guardian of property, and the unswerving course of Justice and Right were also there. The sisters stood there without a champion, waiting to see Deucalion and his people, begging for a leader. For there was no possibility of travelling free from worry, nor had their fear completely disappeared because the Furies had been driven into hell. At last the lofty brow of Jupiter began to tremble as it gave birth to Minerva and the whole sky echoed as it turned on a greater axis. No day was ever more pleasing to the gods. Coming from this father, born in this way, Pallas, the guardian and leader of the virtues, cleared the path of the gods and banished the Furies and the monsters." 16

Here again comes the theme from the introduction to book two: Pallas as defence from the Furies. Besides, the model of this passage has been again provided by Claudian. ${ }^{17}$ In his panegyric Laus Stilichonis there is a passage: Piety (Clementia), living in Jupiter's sphere, was the initial guardian of the great universe. She was the first to organize the Chaos, having pitied the rough mixture; chased gloom off and washed the world in light. She created herself an altar in the chest of Stilicho and taught him to avoid bloodshed, to forgive faults, etc. Together with her, her sister Fidelity (Fides) found an altar in his heart, also teaching him. After that a whole group of virtues instructs him: Justice, Patience,

16 Translation by A. K. Bate $(1986,99)$.

17 It should be noted that such a motive as the expulsion of the Furies to Tartarus is another proof of the generic connection with panegyric, but not with epic. A heroic poem needs the Furies who are free to move, and to lock them in hell is to create a picture of the Golden age, for which it is one of its prerequisite elements. 
Prudence, Constancy. Meanwhile hostile spirits (numina) born in the caves of Tartarus are chased away. They are Greed, Ambition, Voluptuousness, and others (Stil. 2. 6-172).

The likeness of the two situations is evident: creation of cosmos (Claudian) - its renovation after the flood (Joseph), Piety as guard of the universe (Claudian) - Pallas as guard of virtues ${ }^{18}$ (Joseph), personified virtues and their enemies, infernal spirits (Furies / vices), chased off to Tartarus ${ }^{19}$. It is important that in the context of this scene we observe transformations in characters initially belonging to the sphere of mythology. K.S. Lewis aptly named this Claudian passage "psychomachy" (Lewis 1958, 73). When Joseph places Pallas and the Furies in the situation of psychomachy, these figures are forcedly turned into similar to those they share the scene with, thus embodying allegoric meanings. Pallas next to Venus and Juno is an epic goddess, Pallas next to Fidelity and Patience is closer to personified wisdom.

Finally, we can parallel the discussed passage of the Ylias with an amazingly similar extract from the Elegia by Henry of Settimello (1193):

\section{Hanc, Pater, hanc animam, misero quam carcere trudis, hanc lacrimis plenam suscipe, redde polo. \\ Alme parens, animam, quam pene turba flagellat, suscipe quam Stigiis tritat Erinis aquis, \\ quam ferit Allecto quam Thesiphoneque fatigat, cui Fortuna nocet quave Megera furit. \\ Ergo pium pietas te reddat, ut impia cesset} Allecto, miserum que lacerare sitit.

(Elegia 2. 21-28).

"O Father, accept this soul full of tears, which you have locked in a solemn dungeon and return it to the heavens. Good father, accept this soul being flogged by a crowd of punishment, being exhausted by Erinyes in the waters of Styx, being beaten by Allecto, being tortured by Tisiphone, being harmed by Fortune, being raged over by Megaera. Let mercy make you merciful to stop the wicked Allecto, eager to torment the miserable." (Translation mine.)

In case of the Elegia, there are no doubts as to who the narrator is. It is an appeal of a Christian poet to a Christian god (Pater, alme parens), while we also meet the Platonic metaphor of a dungeon, the Platonic motive of return to heavens adopted by Christianity (both authors use the phrase redde polo, see below), and a developed theme of the raging Furies. $^{20}$

18 Cf. morum prudentia custos (Ylias 4. 128).

19 It's worth noting that: 1) from both Claudian sources, the invective In Rufinum and the panegyric De consulatu Stilichonis, Joseph lifts similar episodes: personified virtues / vices and their role in creating and maintaining the cosmos; 2) the metaphor of heart as a temple of virtues, colorfully developed by Claudian, is an indirect argument for allegoric understanding of Trojan sanctuaries and the endeavors of the Furies to seize them.

20 The allegoric nature of the Furies in the Ylias allows for questioning in front of whom and for whom Allecto recites her monologue before attacking Priam. A. Rigg finds in Joseph's works five types of attitude towards paganism, applied metonymy included. This metonymy is realized in arts, which the medieval poet connects to classical traditions. Thetis is the metonymy of the sea, but in myths she is also Achilles' mother and is searching exactly for him; Aurora is the daybreak, but she is Memnon's mother and mourns him. Pallas is the personification of wisdom, but traditionally it is Achilles she watches over. And Joseph does not allow Pallas, offended by the Judgment of Paris, to instruct any Trojan hero in wisdom (Rigg 2001, 24). It should be added that rhetoric declamation through such metonymy is one of the ways of detalisation. Book I includes an episode when Hercules with the Greeks attacks Troy, starting a battle. Nereus sees waters 
Thirdly the story of the Fall and in particular the phrase funera exilii tui.

The image of exile (and return to one's genuine fatherland), having a Neoplatonic tinge, was known to Joseph of Exeter from at least two late ancient authors: Boethius (Cons. 1. pr.5. 2-5) and Macrobius: Quod autem ait nihil infra lunam esse divinum praeter animos munere deorum hominum generi datos non ita accipiendum est animos hic esse ut hic nasci putentur, sed sicut solem in terris esse dicere solemus, cuius radius aduenit et recedit, ita animorum origo caelestis est sed lege temporalis hospitalitatis hic exulat (In Somn. 1.21.33-34). In connection with the theme of return to fatherland / to the genuine good Boethius uses redux three times (Cons. 2. pr.8. 5; 3. m.9. 21; in particular 4. m.1. 23-26); cf. Joseph's: redde polo reduces. So, the semantics of exile and return in the passage discussed has platonic connotations, although it can be easily reinterpreted in the Christian tradition (since it corresponds with the concept of the Expulsion from the Garden of Eden). ${ }^{21}$

Thus, there really are grounds to believe that all the images in the introduction that A. G. Rigg sees as religiously incompatible, can be read from two perspectives, both pagan and Christian. But having removed the difficulty exposed by Rigg, we have come across another one. Why does Joseph need this passage that allows for a double interpretation? Let us go over its compositional place.

As was said above, the main part of book two of the Ylias is dedicated to the dream of Paris about three goddesses. As an author describing a dream, Joseph finds himself under the influence of Macrobius. Symptomatically, Paris, when starting to talk about his dream, says: "Not the dream playing quarrelsome jokes on common people (in plebem) came to me, but the one that befits kings" (2. 231-233): cf. Macrobius' note that dreams about state affairs are seen as genuine only if they come to a governor or a magistrate. But they have to come to more than one commoner (de plebe) to be accepted in the same way. Homer can be an example of this when he makes Nestor comment on the dream of Agamemnon that in the affairs of state we can only believe a dream of a king (regio somnio); and if it were a dream of somebody else, we would reject it as vain (Macrob. In Somn. 1.3.14-15).

Macrobius singles out five types of dreams, leaving two of them out as vain and seeing the remaining three as prophetical. First of all comes the oraculum ("when in a dream a parent or another sacred or important person, or a hierophant, or even a god clearly announces what will happen or not happen, what is to be done and what is to be avoided"); secondly, visio ("when something a person sees happens in the very same way"; e.g. you

turn red and is horrified. To make sure that the Ocean still sheds water, not blood, he hastens to its sources which Joseph sees ancient-like: an urn, shedding water. After this he delivers a monologue of 11 verses (1. 376-386), addressing all the sea gods and asking them to drown the criminal Greeks and Phrygians. This monologue concludes the picture by the sea, the author turns to Troy, and the episode with Nereus has no continuation. Translated into reality it only means "the blue sea turned black", but the comprehensive personification creates some kind of a chamber theater, declamation "for itself", limited by its own space and needing no public and no plot development. Thus, the monologues of Nereus and Allecto are poetic elements of the same kind.

${ }^{21}$ Cf. Radulfus Ardens Homiliae 57: Nos quoque, fratres mei, advenae sumus in exsilio huius mundi, tum quia creati fuimus in primo parente nostro, ut essemus cives coeli, a quo per primam praevaricationem eiecti sumus in hoc exsilium, tum quia maior pars nostri anima, natione coelestis, non terrena est (PL 155. 1878); Honorius Augustodunensis. Speculum ecclesiae: ...ut post huius vitae exilium mereamini cum illo in superna patria obtinere illius gloriae honorem, quam oculus non vidit nec auris audivit, et caetera (PL 172. 844); Christianum populum eripuit Dominus de exilio huius vitae cum activa et contemplativa vita, ad patriam paradysi tendentem (ibid., 930); Martinus Legionensis. Sermones. 7: Sed cum finito tempore nostri exsilii ventum erit ad patriam, tunc utraque decorabitur stola (PL 208. 605), etc. 
see a friend of yours, who for a long time was abroad, come back, and he does come back); thirdly, somnium in a narrow sense (it differs from the two above-mentioned types being metaphorical, and to be understood it has to be interpreted). Macrobius also underlines that dreams can be complex, and, in particular, the dream of Scipio can be classified to include all the three types mentioned (Macrob. In Somn. 1.3.1-12).

So, what kind of a dream does Paris see? On the one hand, it is oraculum: he sees goddesses, telling him what to do (to prefer one of them and get her as a patron). On the other hand, depicting Pallas as a patron of virtues, Joseph hints that the dream is metaphorical (somnium). But these different sides of Paris' dream are discovered by different interpreters: for the dreamer himself, pagan Paris, it is oraculum: he believes in the existence of goddesses whom he saw and takes their instructions in earnest. For the author of the poem, a Christian Joseph and his contemporaries, it is somnium, a dream of enigmatic nature. It says that wisdom should have been chosen to protect virtues and save one from the Furies. And if you opted for lust with its insatiable attractions, then it is only you who is to blame.

Joseph of Exeter needed to depict the dream of Paris in such a way that it made sense from the standpoint of two religions. Part of it was to create tragic irony: Paris is triumphant, as he obtains the benevolence of a goddess, while a Christian reader foresees the death of the character, who deifies his own voluptuousness. Joseph anticipates this voluminous and ambiguous passage with an equally ambiguous, but shorter introduction. The introduction rightfully bewilders the reader, but is retrospectively explained at the end of the book. It is as ambiguous, as is the dream of Paris: it prepares the reader for the dream and together with it contributes to the conclusion of book two. Depending on whom they face, the Furies change their appearance. For Priam and Paris they are the same devil's incarnations that in classical times drove Amata crazy and educated Rufinus. For a Christian reader they are personifications taken from allegoric mythographers. The way a prophetic dream belongs to the one who manages to interpret it, the tirade that caused Rigg's doubts is property of the pagan character and the Christian author alike, who both have keys to unlock it.

\section{Bibliography}

Bate A. K. (ed., transl., comm.) Joseph of Exeter. Trojan War. Vols I-III. Warminster, Aris \& Phillips, 1986.

Clarke A. K., Giles P.M. (eds). The Commentary of Geoffrey of Vitry on Claudian "De raptu Proserpinae". Leiden - Köln, Brill, 1973.

Colker M. (ed.) Galteri de Castellione Alexandreis. Padova, In aedibus Antenoreis, 1978.

Gompf L. (ed.) Joseph Iscanus. Werke und Briefe. Leiden — Köln, Brill, 1970.

Jones J. W., Jones, E. F. (eds). Bernardus Silvestris. The Commentary on the First Six Books of the Aeneid of Vergil Commonly Attributed to Bernardus Silvestris. Lincoln - London, University of Nebraska Press, 1977.

Kratz D. Mocking Epic: Waltharius, Alexandreis and the Problem of Christian Heroism. Madrid, Ediciones Jose Porrua Turanzas, 1980.

Lewis C.S. The Allegory of Love. A study in medieval tradition. New York, Oxford University Press, 1958.

Nauta L. (ed.) Guillelmus de Conchis. Glosae super Boetium. Turnhout, Brepols, 1999.

Panofsky E. Renaissance and renascences in Western art. New York, Harper \& Row, 1972.

Parker H. C. The pagan gods in Joseph of Exeter's 'De bello Troiano'. Medium Aevum 1995, 64, 273-278.

Rigg A. G. A history of Anglo-Latin literature, 1066-1422. Cambridge, Cambridge Universsity Press, 1992.

Rigg A. G. Joseph Of Exeter's Pagan Gods Again. Medium Aevum 2001, 70, 19-28.

Wetherbee W. (ed., transl.) Johannes de Hauvilla. Architrenius. New York, Cambridge Universsity Press, 1994.

Wrobel I. (ed.) Eberhardi Bethuniensis Graecismus. Vratislaviae, In aed. G. Koebneri, 1887.

Received: April 25, 2019

Accepted: September 27, 2019 